\title{
Financialization and demand regimes in advanced economies
}

Engelbert Stockhammer and Karsten Kohler April 2019 


\title{
Financialization and demand regimes in advanced economies
}

\author{
Engelbert Stockhammer* and Karsten Kohler**
}

\begin{abstract}
In this article, we analyze the implications of financialization for domestic demand formation by linking the concept of financialization to the post-Keynesian analysis of demand regimes. We examine how the financialization of households in advanced economies gave rise to distinct but interdependent demand regimes. In the Anglo-Saxon and southern European countries, financialization in the form of property price inflation and rising household debt contributed to the development of a debt-driven demand regime with large current account deficits. Economic development in eastern Europe was shaped by catching-up through foreign direct investment from northern Europe and accompanied by worsening current account positions. Northern Europe, in contrast, relied on an export-driven demand regime with a weaker role for financialization. The export-driven demand regime relies on the financialization of southern Europe and the Anglo-Saxon countries, which helped create export demand for northern Europe. We argue that this constellation of demand regimes gives rise to divergent economic performance and macroeconomic instability. While with deleveraging the growth effects of the debt-driven model have gone into reverse, the fundamental configuration has not changed since the crisis.
\end{abstract}

Keywords: Financialization, demand regimes, post-Keynesian economics

Acknowledgements: We would like to thank Daniel Mertens for helpful comments. All remaining errors are the authors'.

\footnotetext{
* Department of European and International Studies, King's College London. Virginia Woolf Building, 22 Kingsway, London, WC2B 6LE. Email: engelbert.stockhammer@kcl.ac.uk.

** Department of Economics, Kingston University London, KT1 2EE, Kingston upon Thames, UK.
} 


\section{Introduction}

Inspired by the interdisciplinary debate about financialization, International Political Economy (IPE) scholars have incorporated notions of finance-led growth in their explanations of the euro crisis (Becker and Jäger 2012; Overbeek 2012; Ryner 2015). However, this is often done with a limited treatment of the macroeconomic dynamics of financialization. Post-Keynesian economics (PKE), in contrast, is by its very nature concerned with the macroeconomic outcomes of financialization. On a theoretical level, there has been a debate under what conditions financialization can have expansionary effects on aggregate demand (Boyer 2000; Dutt 2006; Skott and Ryoo 2008; van Treeck 2009; Hein 2012, chap. 3). Empirical research on financialization has demonstrated negative effects on firm investment (Stockhammer 2004; Orhangazi 2008; Tori and Onaran 2017) and functional income distribution (Dünhaupt 2016; Stockhammer 2017; Kohler et al. 2018), but expansionary effects of household debt on consumption and of property prices on investment (Kim et al. 2015; Stockhammer and Wildauer 2016).

Post-Keynesians have also developed a typology of macroeconomic regimes allowing for cross-country comparative analysis. They distinguish wage-led and profit-led (Bhaduri and Marglin 1990; Lavoie and Stockhammer 2013), as well as export-driven and debt-driven demand regimes (Hein 2013; Stockhammer 2011, 2016). A comparative approach is also used by the proponents of Varieties of Capitalism ( $\mathrm{VoC}$ ) who offer a typology of economies based on their comparative institutional advantages (Hall and Soskice 2001). VoC, however, has a strong focus on supply-side factors and regards labour relations as the key institutional determinant of different regimes. It tends to neglect the problem of aggregate demand formation and has not yet fully included financialization into its analysis.

In this article, we adopt a PK approach to examine how different degrees of the financialization of households in the decade prior to the Global Financial Crisis (GFC) fostered the development of distinct demand regimes. ${ }^{1}$ Second, we analyze the interdependence and sustainability of these demand regimes. Lastly, we assess if the regime configuration that has

\footnotetext{
${ }^{1}$ While the basic macroeconomic mechanisms that underpin export- and debt-driven demand regimes have been in place for a long time, we believe that the institutional configurations that allowed for the development of distinct export- and debt-driven demand were only created since the 1980s. A key institutional pre-condition for the development of these interdependent regimes is the liberalisation of international capital flows, which in Europe took the form of the European Monetary Union. This allowed credit booms and trade imbalances to amplify and thus for the emergence of strong and long-lasting export and debt-driven demand episodes.
} 
prevailed before the crisis has undergone changes in the post-crisis period. Our focus is on advanced countries, in particular Europe and the USA. We show that in the Anglo-Saxon and southern European countries, financialization contributed to the development of a debt-driven demand regime, in which mortgage securitisation and capital inflows facilitated a boom in residential investment. The latter led to property price inflation, rising household debt, and ultimately large current account deficits. ${ }^{2}$ Macroeconomic dynamics in eastern Europe were shaped by catching-up through foreign direct investment from northern Europe with worsening current account positions. Northern Europe, in contrast, relied on an export-driven demand regime with a weaker role for domestic financialization. The export-driven demand regime relies on the financialization of southern Europe and the Anglo-Saxon countries, which helped create export demand for northern Europe. We find that this configuration of demand regimes gives rise to divergent economic performance and macroeconomic instability. Despite some deleveraging in the Anglo-Saxon and southern Europe countries at the downturn of the financial cycle, the configuration that has contributed to the crisis has not fundamentally changed.

The article is structured as follows: the second section briefly introduces the post-Keynesian concept of demand regimes. The third section examines how different forms of financialization gave rise to different demand regimes in advanced economies. The fourth section compares the PK analysis to IPE and VoC approaches to the euro crisis. The last section concludes.

\section{Demand regimes}

The concept of effective demand is the unifying theme for PKE. ${ }^{3}$ In a situation of involuntary unemployment the level of effective demand will determine the level of output. In its analysis of demand regimes, PKE has highlighted the effect of changes in income distribution on effective demand through the distinction of wage-led vs. profit-led demand regimes (Bhaduri and Marglin 1990; Lavoie and Stockhammer 2013). If the expansionary effect of a rise in the wage share on consumption outweighs the negative effects on investment and net exports, the demand regime is called wage led, but if the net effect on aggregate demand is negative, it is profit-led. Empirical research on wage-led vs. profit-led demand regimes tends to find more

\footnotetext{
2 The term 'financialisation of households' could be defined by household debt. The concept of a 'debt-driven demand regime' claims that household debt (and property prices) become a key causal factor for domestic aggregate demand formation and thus macroeconomic performance. The two concepts are thus linked, but distinct. ${ }^{3}$ Lavoie (2006) provides an introduction and Lavoie (2014) a more advanced overview of PKE; see King (2002) and Hein (2017) for historical surveys.
} 
evidence for wage-led than profit-led demand regimes, but generally concludes that the distributional effects on aggregate demand are rather modest (Hein 2014, pp. 300-307).

Consequently, PKs have identified two additional growth models that have been empirically fruitful to analyse economic trajectories under neoliberal capitalism: debt-driven and exportdriven growth (Hein 2013; Stockhammer 2011, 2016). As financialisation involved rising levels of private debt due to financial innovations and easier access to credit, the possibility of a debt-led demand regime has been analysed by post-Keynesians from a macroeconomic point of view (Boyer 2000; Dutt 2006; Skott and Ryoo 2008; van Treeck 2009; Hein 2012, chap. 3). Expansionary effects on consumption can arise if the recipients of financial incomes have a comparatively high propensity to consume or if asset price inflation leads to wealth effects on the consumption demand. On the other hand, financialization may have contractionary effects on consumption if rentiers have a lower propensity to consume than debtors, and if financialization redistributes income from workers to firms with a higher propensity to save. Rising property prices can have expansionary effects on residential investment through wealth effects. Contractionary effects on business investment may result from a loss of means of internal finance due to rising financial payouts or from a shift from real accumulation toward financial accumulation. In an empirical study, Stockhammer and Wildauer (2016) find positive effects of household debt on consumption, and of property prices on total investment Regarding the effects of financial payments and financial income of non-financial corporations' investment decisions, the empirical literature mostly finds contractionary effects (Stockhammer 2004; Orhangazi 2008; Tori and Onaran 2017). If that is correct, a debt-driven regime would require that the expansionary effects on consumption and residential investment outweigh the contractionary effects on non-residential investment.

While the possibility of an export-driven demand regime is economically straightforward, its link to financialization may not be obvious. Post-Keynesians have argued that financial liberalisation (for instance in the context of European integration) facilitates the development of an export-driven demand regime for competitive economies, as it eases the access of deficit countries to foreign credit (Storm and Naastepad 2015). Moreover, empirical research shows that export-driven demand regimes exhibit weak correlation with several dimensions of domestic financialization such as corporate leverage and the size of the financial sector (Karwowski et al. 2017). This suggests that export-driven regimes are domestically only weakly financialized themselves but rely on the financialization of their trading partners. 
Importantly, debt-driven and export-driven demand regimes are interdependent. As the debtdriven model involves significant gross and net capital inflows that stimulate asset price inflation, domestic credit growth, and import demand, it effectively constitutes the mirror image of the export-driven demand regime, which relies on the debt-financed trade deficits of other countries. Thus, both debt- and export-driven demand regimes allow for growth but are intrinsically unstable, because they require increasing debt-to-income ratios. In the case of the debt-driven model it involves domestic private debt; in the case of the export-driven model it requires foreign debt of the trade partners.

\section{Financialization and demand regimes}

\subsection{Financialization}

Financialization is often measured by the size (Brown et al. 2017) or profitability (Krippner 2005) of the financial sector. However, cross-country studies (Karwowski et al. 2017) have shown that financialization has several dimensions and does not affect all economic sectors equally. Due to its multidimensionality, it cannot be reduced to measures that are related to the financial sector only. For instance, Karwowski et al. (2017) show that the category of marketbased (as opposed to bank-based) financial systems, that is often being used in the VoC literature as a measure of financialisation, is correlated only with the financialization of firms, but not households. In contrast, we argue that it was precisely the financialization of households that has played the key role in determining demand regimes in the decade prior to the GFC. Domestic credit (and especially its growth in recent years) has been driven by mortgage credit, not credit to businesses. Thus, disregarding the financialization of households can be misleading when assessing country-specific financialization dynamics. In particular, the financialization of southern Europe is understated when focusing only on measures for the size or profitability of the financial sector (e.g. see Table 2 in Brown et al. 2017, where the financialization trends of most southern European countries are classified as stable or moderate).

We are specifically concerned with the impact of financialization on demand formation and the extent to which it has allowed for a debt-driven model. Thus, our analysis of financialization focuses on household debt and property prices. ${ }^{4}$ We will measure this by the debt-to-net disposable income ratio for households and by real property prices (i.e. property prices relative

\footnotetext{
${ }^{4}$ While household debt in advanced economies also includes consumer credit, student loans, and loans for medical bills, mortgage debt typically constitutes the lion's share (Zabai 2017, Table 1).
} 
to consumer prices). We argue that the debt-driven demand regime is intimately linked with the export-driven model via trade- and capital flows from the export-driven to the debt-driven countries. To measure the extent to which a country is export-driven, we use the current account-to-GDP ratio.

Following Stockhammer et al. (2016), we group advanced economies into northern Europe, southern Europe, the Anglo-Saxon countries, and eastern Europe. The country groupings are based on our explanation of the demand regimes in the decade before the crisis. We choose a few representative countries for each group. Northern Europe will be Germany, Austria, and the Netherlands. These are countries of the Germanic block within the Euro area. They all follow an export-driven model with limited domestic financialization (with the exception of the Netherlands, where household debt grew fast). Southern Europe will consist of Greece, Ireland, Italy, Portugal, ${ }^{5}$ and Spain. These are the peripheral countries within the Euro area that were hit hard by the crisis (often called the GIIPS countries). We argue that these are debtdriven demand regimes that are strongly shaped by financialization. We further analyse the Anglo-Saxon countries USA and the United Kingdom that also exhibit the characteristics of debt-driven regimes but with some specificities that separate them from southern Europe. Lastly, the eastern European group consists of Poland, the Czech Republic, Slovakia, Hungary, and Slovenia. These are post-communist economies that have undergone a foreign direct investment (FDI)-based catching-up process after opening up to the West in the 1990s.

Our grouping of countries serves the purpose of illustration. They are very similar to those offered by the VoC literature. Amable (2003) and Hassel (2014) extend the basic coordinated and liberal market economy groups by a Mediterranean or Mixed Market group, which is almost identical to our southern group, and Nölke and Vliegenthart (2009) use a Dependent Market Economy group, which corresponds to our East. The motivation for the country groups, however, is different. While VoC offers a general classification of models of capitalism based on institutional characteristics, our analysis focuses on household financialisation and exportorientation and their implications for demand formation.

There are several potential issues. First, the delineation of groups is arbitrary at the border and one could include Scandinavian countries. Within the northern group, the Netherlands is an

\footnotetext{
${ }^{5}$ Hein (2013) classifies Portugal and Italy as domestic demand-led demand regimes.
} 
interesting intermediate case that has elements of an export-driven as well as of a debt-driven economy. Second, as regards the southern group, the question is whether Italy should be included or not. We include it but note that it does not display the characteristics of a debtdriven regime to the same extent as other countries in the group. Moreover, although geographically not part of southern Europe, we include Ireland as it belonged to the group of countries that were at the heart of the European sovereign debt crisis. It is sometimes classified as a liberal market economy by VoC (e.g. Hassel, 2014). Amable (2003) classifies Ireland as part Continental European Capitalism, which corresponds to the coordinated model. We argue that it better fits into the southern group as its increase in household debt is much higher than that of the USA and UK, and because it does not dispose of a sovereign currency and is thereby constrained in its monetary autonomy.

\subsection{Financialization and demand regimes in advanced economies}

We cover the period before the crisis (2000-2008), as well as the post-crisis period (20082016). Table 1 describes the financialization of households in Europe and the United States, measured by changes in household debt and property prices. In the period before the crisis, household debt as percentage of the net disposable income of households increased by $23.7 \%$ pts in northern Europe, 36.2\%-pts in eastern Europe, 47.7\%-pts in the Anglo-Saxon countries, and by a staggering 62.2\%-pts in southern Europe. Household debt is to a large extent driven by house prices (Stockhammer and Wildauer 2017). In the pre-crisis period, these grew by $3.3 \%$ in real terms in northern Europe, but by considerable $52.9 \%$ in southern Europe, and by $60.5 \%$ in the Anglo-Saxon countries. 
Table 1: Changes in the financialization of households, 2000-2016

\begin{tabular}{|l|c|c|c|c|}
\hline & \multicolumn{2}{|c|}{$\Delta$ Household debt (\%GDP) } & \multicolumn{2}{c|}{ Real house prices, growth } \\
\hline & $2000-2008$ & $2008-2016$ & $2000-2007$ & $2007-2016$ \\
\hline Austria & 14.4 & 1.8 & $-0.3 \%$ & $37.8 \%$ \\
\hline Germany & -17.1 & -6.0 & $-12.8 \%$ & $18.2 \%$ \\
\hline Netherlands & 74.0 & -4.4 & $23.2 \%$ & $-17.8 \%$ \\
\hline Mean (northern Europe) & 23.7 & -2.9 .8 & $3.3 \%$ & $12.7 \%$ \\
\hline Greece+ & 56.8 & 31.3 & $52.4 \%$ & $-43.8 \%$ \\
\hline Ireland*+ & 118.9 & -51.9 & $70.8 \%$ & $-33.1 \%$ \\
\hline Italy & 27.1 & 6.6 & $45.1 \%$ & $-26.1 \%$ \\
\hline Portugal & 42.1 & -11.7 & $-10.5 \%$ & $-13.8 \%$ \\
\hline Spain & 66.0 & -32.9 & $106.6 \%$ & $-36.6 \%$ \\
\hline Mean (southern Europe) & 62.2 & -11.7 & $52.9 \%$ & $-30.7 \%$ \\
\hline Czech Republic+ & 37.2 & 9.0 & & $-1.2 \%$ \\
\hline Hungary+ & 59.8 & -28.7 & & $-10.9 \%$ \\
\hline Poland+\# & 39.7 & 12.7 & & $-9.9 \%$ \\
\hline Slovakia+ & 23.7 & 26.4 & & $-4.7 \%$ \\
\hline Slovenia*+ & 20.5 & 3.5 & & $-24.5 \%$ \\
\hline Mean (eastern Europe) & 36.2 & 4.6 & & $-10.2 \%$ \\
\hline United Kingdom & 63.2 & -18.2 & $85.7 \%$ & $-5.0 \%$ \\
\hline USA & 32.3 & -24.6 & $35.2 \%$ & $-8.3 \%$ \\
\hline Mean (Anglo-Saxon & & & & $-6.6 \%$ \\
\hline countries) & 47.7 & -21.4 & $60.5 \%$ & $-12.0 \%$ \\
\hline Total mean & 43.9 & -5.8 & $39.5 \%$ & \\
\hline
\end{tabular}

Sources: OECD. Own calculations.

Notes: $\Delta$ denotes change over time. * Household debt data only from 2001. + Household debt data only until 2015.

$\sim$ House price data only from 2008. \# House price data only from 2010. No data on house prices for Eastern European countries between 2000 and 2007.

Overall, northern Europe experienced only a weak form of financialization of households in the pre-crisis period, with household debt and asset prices growing at comparatively low rates. An exception is the Netherlands which underwent a surge in household debt and house price inflation. The southern European and Anglo-Saxon countries, in contrast, experienced strong 
financialization with a marked increase in household debt and house prices. Eastern European countries had an intermediate form of financialization with household debt increasing more than in northern Europe, but less than in the southern and Anglo-Saxon countries.

Looking at the post-crisis period, we observe a strong reduction in household debt of $-21.4 \%$ pts and -11.7\%-pts in the Anglo-Saxon and southern European countries, respectively. In the northern European countries, household indebtedness fell slightly by $-2.9 \%$-pts, while it moderately grew by $4.6 \%$ in eastern Europe. The trajectories observed in the Anglo-Saxon and southern European countries are also reflected in house prices which fell by $-6.6 \%$ and $-30.7 \%$, respectively. Eastern Europe experienced declining house prices (-10.2\%) despite its increase in household debt, indicating that the strong positive link between household debt and house prices that is so characteristic of the financialization era is less tight in these economies. Similarly, northern Europe experienced house price growth (12.7\%) despite falling household debt, but at a comparatively moderate rate. However, most notable is the deleveraging of the southern and Anglo-Saxon countries in the post-crisis period, which is characteristic of the downturn phase of a financial cycle.

Table 2 summarises the development of the external sector as captured by the current account balance in relation to GDP. It also provides average real GDP growth, as demand is a key determinant of net exports. In the pre-crisis years, we note a strong current account surplus in northern Europe of about $4.1 \%$ of GDP on average, combined with moderate GDP growth of 2.1\%. The Netherlands exhibit strong current account surpluses despite a fast growth in household leverage, which suggests that its export performance overcompensated strong domestic demand growth. The Anglo-Saxon, eastern and southern European countries, in contrast, exhibited large current account deficits of $-3.3 \%,-5 \%$ and $-5.5 \%$ of GDP, respectively. In southern Europe, the deficit is clearly linked to strong GDP growth. In the postcrisis period, the qualitative pattern of current account imbalances persists, but the crosscountry variance declined somewhat (as indicated by a lower standard deviation of 3.9 compared to 4.6 in the pre-crisis period). This slight decrease in current account imbalances is entirely due to the reduction of current account deficits in southern and eastern Europe. These two groups managed to reduce their deficit to about $-2.8 \%$ and $-0.7 \%$ of GDP, respectively, while the northern European economies even increased their current account surplus to about $5.8 \%$ of GDP on average. In the southern European countries, this decrease is without a doubt due to the severe decline in import demand in the wake of harsh austerity measures (average 
GDP growth was $-0.4 \%$ in the post-crisis period). It is noteworthy that the Anglo-Saxon countries, despite being at the centre of the financial crisis in its first years, did not manage to reduce their current account deficits significantly as they realised above average growth rates in the post-crisis period.

Table 2: External sector and GDP growth, 2000-2016

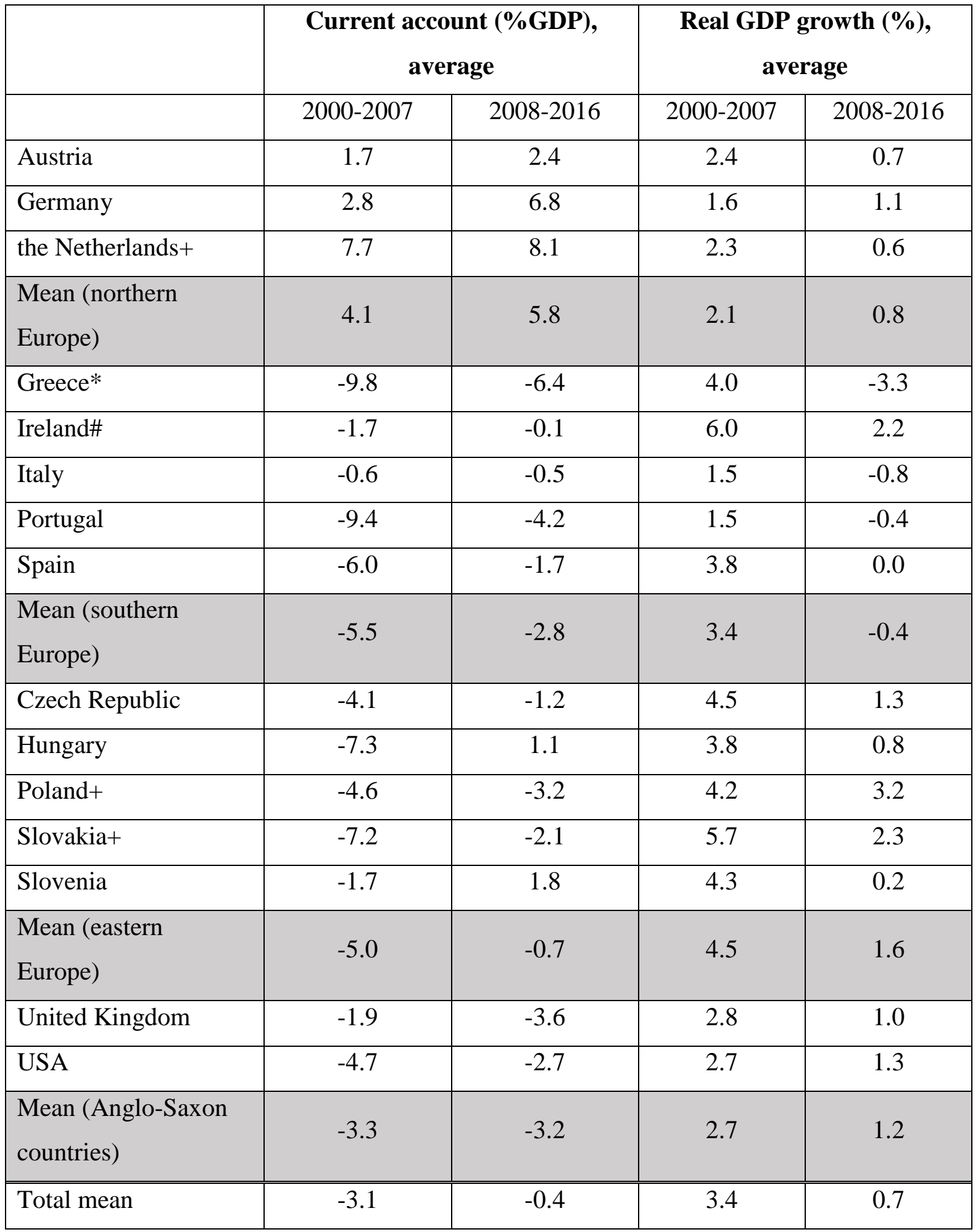




\begin{tabular}{|l|c|c|c|c|}
\hline $\begin{array}{l}\text { Total standard } \\
\text { deviation }\end{array}$ & 4.6 & 3.9 & 1.4 & 1.5 \\
\hline
\end{tabular}

Sources: Current account: AMECO; GDP: OECD. Own calculations.

Notes: * Data only from 2002. + Data only from 2004. \# Ireland's 2015 GDP growth rate of 25.6\% was excluded from the average as it was mostly driven by changes in the residency of several multinational corporations

Our examination of changes in financialization of households and the external sector suggests that the demand regime of the northern European countries is based on a strong export orientation with weak dynamics of financialization (with the exception of the Netherlands). Stockhammer et al. (2016) further show that the northern European countries maintained a relatively stable share of manufacturing in GDP, while other European economies underwent de-industrialisation. Together with comparatively moderate levels of inequality, this configuration creates a stable environment in which long-term finance allows firms to invest in high value-added goods for the export market, while domestic consumption and residential investment play a secondary role. With respect to the post-crisis experience, we note that the northern European countries have reinforced their export orientation. While household indebtedness and property prices are on the rise, the dynamics are quantitatively nowhere near the boom the southern European and Anglo-Saxon countries underwent prior to the crisis.

The southern countries experienced a strong wave of financialization of households with sharply increasing levels of household debt and a property price boom in the period before the crisis. While some authors point to rising inequality as the key driver behind the surge in US household debt (Barba and Pivetti 2009; Frank et al. 2014), household indebtedness in southern Europe seems to have been driven by asset price inflation as changes in income inequality were comparatively moderate. The strong growth in asset prices and private credit was partly caused by gross and net portfolio credit flows from northern Europe and the Anglo-Saxon countries (Hale and Obstfeld 2016; Lane and McQuade 2014). The resulting boom in consumption and residential investment was accompanied by large current account deficits. ${ }^{6}$ The experience of the southern European countries before the crisis thus fits well into the PK category of debtdriven demand. The post-crisis development was strongly shaped by the deleveraging of households in a context of weak macroeconomic performance due to harsh austerity packages. Due to their membership in the European Monetary Union (EMU), these countries could not

\footnotetext{
${ }^{6}$ Guschanski and Stockhammer (2017) find that rising asset prices are a key determinant of current account deficits.
} 
resort to quantitative easing to support expansionary fiscal policy (Stockhammer 2016). Moreover, the period prior to the crisis was characterised by a marked de-industrialisation (Stockhammer et al. 2016) rendering these economies very vulnerable to adverse shocks to their debt-driven domestic demand model. As a result, house prices collapsed, and aggregate income decreased severely resulting in a reduction of current account deficits.

The Anglo-Saxon countries exhibit a similar demand regime to the southern European countries but with some noteworthy differences. They have experienced a slightly less pronounced but still remarkable process of financialization, reflected in strong household debt growth coupled with a property price bubble that stimulated private consumption demand and residential investment. The resulting boost to import demand led to a deficit position in the current account. Different from the southern European countries, high levels of inequality in these countries arguably contributed to the surge in household debt, as workers tried to keep up with social consumption norms despite constant or declining real wages (Stockhammer 2015). In the post-crisis period, the Anglo-Saxon countries experienced a strong deleveraging of households, even surpassing the development in southern Europe. Property prices dropped as well, though less dramatically than in southern Europe. A remarkable difference in the postcrisis development of the Anglo-Saxon and southern European countries concerns the current account. While the southern countries significantly reduced their deficits, the Anglo-Saxon countries maintained their large deficit position. There are at least two reasons for this phenomenon. First, the Anglo-Saxon countries were more successful in fighting the 2009 recession by means of expansionary fiscal policy supported by accommodative monetary policy. Monetary policy sovereignty is an important pre-requisite for such an approach and constitutes a key difference to the situation of the southern EMU members (Stockhammer 2016). Second, while the Anglo-Saxon countries also underwent de-industrialisation prior to the crisis, they maintained their role as global financial centres. This sustained domestic import demand and allowed for a smooth flow of foreign capital financing their external deficits. From a post-Keynesian perspective, the Anglo-Saxon countries clearly fall into the category of a debt-driven demand regime.

The eastern European countries experienced a medium wave of financialization of households prior to the crisis. While household debt did play a role, it was (with the exception of Hungary) not as marked as in the southern European and Anglo-Saxon countries. The increase in household debt has slowed down in the period after the crisis when property prices fell. The 
current account deficit significantly improved in the post-crisis period. Overall, the Eastern European countries underwent quite different dynamics compared to the Anglo-Saxon and southern European countries with which they share the current account deficit position. The opening of the financial account in conjunction with the privatisation of formerly public enterprises created a boom in foreign ownership. Stockhammer et al. (2016) argue that more important than household debt was a surge in FDI inflows that modernised parts of industry and subsumed them into German commodity chains. A part of these FDI inflows came from northern Europe, where firms were actively outsourcing segments of production to reduce production costs. This process has helped build a competitive productive structure in eastern Europe but went hand in hand with current account deficits prior to the crisis. Thus, while eastern Europe is linked to the export-driven model, it is characterised by the subordinate catching up process with some elements of a debt-driven growth process. Nölke and Vliegenthart (2009) speak of dependent market economies.

Table 4 provides a summary of our classification of demand regimes. We conclude that the financialization of households has played a key role for the development of a debt-driven demand regime in southern Europe and the Anglo-Saxon countries. This is due to the strong impact of rising property prices on (residential) investment and of household debt on consumption demand (Stockhammer and Wildauer 2016). The northern European countries with limited financialization of households, on the other hand, were able to deepen their exportdriven demand regime with a suppressed role for domestic demand. We argue that these demand regimes are interdependent. The export-driven model relies on debt-financed imports from abroad. The southern European countries received gross portfolio capital inflows (from Anglo-Saxon as well as from northern countries (Hale and Obstfeld 2016)) that pushed asset price inflation and helped finance a boom in consumption, residential investment, and ultimately imports. Lastly, the eastern European countries are dependent on the northern countries as they have become more integrated into international supply chains that are dominated by the latter.

Stockhammer et al (2016) argue that these demand regimes came with different implications for income distribution and the welfare state, thus resulting in different class compromises or hegemonic structures. They characterise northern Europe as a retreat of labour, southern Europe as a social compromise backed by a financialization; eastern Europe as dependent catching up and the Anglo-Saxon countries as hegemony by financialization. 
Table 3: Summary of demand regimes

\begin{tabular}{|c|c|c|c|c|c|}
\hline \multirow[t]{2}{*}{ Countries } & \multirow{2}{*}{$\begin{array}{l}\text { Demand } \\
\text { regime }\end{array}$} & \multicolumn{3}{|c|}{ Key characteristics } & \multirow[t]{2}{*}{ Post-crisis trajectory } \\
\hline & & $\begin{array}{c}\text { Financialization } \\
\text { of households }\end{array}$ & $\begin{array}{c}\text { External } \\
\text { sector }\end{array}$ & $\begin{array}{c}\text { Industry and } \\
\text { Finance }\end{array}$ & \\
\hline $\begin{array}{l}\text { Austria, } \\
\text { Germany, the } \\
\text { Netherlands }\end{array}$ & $\begin{array}{l}\text { Export- } \\
\text { driven }\end{array}$ & Moderate & $\begin{array}{l}\text { Current } \\
\text { account } \\
\text { surpluses }\end{array}$ & Industrial centres & $\begin{array}{l}\text { Reinforcement of } \\
\text { export-orientation; } \\
\text { moderate } \\
\text { financialization of } \\
\text { households }\end{array}$ \\
\hline $\begin{array}{l}\text { Greece, Italy, } \\
\text { Ireland, } \\
\text { Portugal, } \\
\text { Spain, }\end{array}$ & $\begin{array}{l}\text { Debt- } \\
\text { driven }\end{array}$ & $\begin{array}{l}\text { Household debt; } \\
\text { property price } \\
\text { bubble }\end{array}$ & $\begin{array}{l}\text { Current } \\
\text { account } \\
\text { deficits }\end{array}$ & $\begin{array}{l}\text { De- } \\
\text { industrialisation }\end{array}$ & $\begin{array}{l}\text { Strong asset price } \\
\text { deflation; } \\
\text { deleveraging of } \\
\text { households; reduction } \\
\text { of current account } \\
\text { deficit; contractionary } \\
\text { fiscal policy }\end{array}$ \\
\hline $\begin{array}{l}\text { United } \\
\text { Kingdom, } \\
\text { United States }\end{array}$ & $\begin{array}{l}\text { Debt- } \\
\text { driven }\end{array}$ & $\begin{array}{l}\text { Household debt; } \\
\text { property price } \\
\text { bubble }\end{array}$ & $\begin{array}{l}\text { Current } \\
\text { account } \\
\text { deficits }\end{array}$ & $\begin{array}{l}\text { Financial } \\
\text { centres; de- } \\
\text { industrialisation }\end{array}$ & $\begin{array}{l}\text { Strong deleveraging of } \\
\text { households; asset price } \\
\text { deflation; quantitative } \\
\text { easing }\end{array}$ \\
\hline $\begin{array}{l}\text { Czech } \\
\text { Republic, } \\
\text { Hungary, } \\
\text { Poland, } \\
\text { Slovakia }\end{array}$ & $\begin{array}{l}\text { Dependent } \\
\text { catching up }\end{array}$ & $\begin{array}{l}\text { Financial } \\
\text { liberalisation; } \\
\text { stock market } \\
\text { bubble }\end{array}$ & $\begin{array}{l}\text { Current } \\
\text { account } \\
\text { deficits }\end{array}$ & $\begin{array}{l}\text { FDI-driven } \\
\text { industrialisation }\end{array}$ & $\begin{array}{l}\text { Strong reduction of } \\
\text { current account } \\
\text { deficits }\end{array}$ \\
\hline
\end{tabular}

This configuration of demand regimes has fostered divergent economic performance and gives rise to macroeconomic instability. The debt-driven model is intrinsically unstable as it is prone to a domestic debt crisis once the property prices bubble bursts. In countries that lack a competitive industrial structure and/or do not happen to be financial centres, this can lead to a drying-up of capital inflows which enforces a reduction of the current account deficit. This is indeed what happened in southern Europe. In countries that can sustain asset prices via quantitative easing and external finance due to their role as financial centres, the bust may be less dramatic. This is what we observe in the Anglo-Saxon countries. However, as these economies were not forced to undertake a fundamental revision of their debt-driven model, another financial crisis may lurk in the near future. For the export-driven northern economies this will have negative feedback effects as they rely on the import demand of their trading partners. Overall, the interrelation of debt- and export-driven demand regimes is an unstable configuration with little prospects for sustainable macroeconomic performance over longer periods.

\section{Interdisciplinary Perspectives: Comparing PKE, IPE, and VoC}

How does our PK analysis compare to IPE and VoC approaches? Within the IPE literature on the euro crisis, there have been some attempts to fuse Marxist inspired analyses of the state and 
class relations with an economic analysis that draws on Marxist, as well as on post-Keynesian arguments. Becker and Jäger (2012), Heyes et al. (2012) and Ryner (2015) are closest to our approach. All of them have a substantial role for financialization but have a limited treatment of the macroeconomic dynamics or the demand regimes involved. Becker and Jäger (2012) offer a contradistinction between export-oriented versus financialized economies similar to ours and, indeed, draw on a similar post-Keynesian literature, while maintaining a Marxistinspired regulationist framework. Ryner (2015) builds most directly on post-Keynesian analysis and uses a similar notion of finance-led growth, however the focus of the paper is on the EU's economic policy regime. Similar to our approach, Heyes et al. (2012) identify exportled growth and finance-led growth as two interdependent accumulation strategies and argue that financialization has led to a weakening of worker's bargaining power through rising indebtedness. Overbeek (2012) stays close to the Marxist framework in asserting an overaccumulation crisis, but notes the importance of finance-led growth, without, however, specifying how financialization affects demand formation. Blyth's (2016) discussion of policy options to overcome the euro crisis does not employ any notions of financialization or financeled growth, but emphasises the interdependence of the export-driven northern European and the debt-driven southern group. In line with our approach, he points to the unsustainability of the export-driven model but does not link his analysis to financialization. Crouch (2009) coins the term 'privatised Keynesianism' to highlight the importance of household debt for domestic demand formation in Anglo-Saxon countries. While he mentions differences to the exportoriented regime, he does not analyse the interaction between the two regimes. Building on this analysis, Watson (2010) develops the cultural dimension of what he calls 'house price Keynesianism' by describing the underlying subjectivities of homeowners and their relationship with financial institutions. Prasad (2012) uses the term 'mortgage Keynesianism' to highlight the key role of mortgage credit for the consumption-driven US-economy.

Thus, there is some overlap between IPE and PKE analyses of the decade prior to the crisis, but also differences. Both approaches assign a key role to financialization. However, while several IPE scholars use the notion of a finance-led growth regime, they fail to analyse the exact channels through which financialization boosts aggregate demand. This is sometimes due to a supply-side focus in Marxist-inspired IPE. Moreover, the macroeconomic interdependence of different demand regimes, while visible in Blyth (2016), has not been fully integrated into the IPE framework. The lack of a serious integration of macroeconomic considerations into the IPE literature has recently also be criticised by Blyth and Matthijs (2017). However, their own 
typology of macroeconomic regimes focuses on key policy targets (full employment or price stability) rather than a comprehensive analysis of aggregate demand formation. Overall, we see complementarities between PKE and IPE with potential for mutual benefit (Stockhammer and Köhler 2015).

VoC proponents analyse the developments in Europe leading up to the crisis as the result of the interaction of the core countries with coordinated wage bargaining and the peripheral countries with weak bargaining coordination in a fixed exchange rate regime without central (European) fiscal policy (Hall 2014; Johnston et al. 2013; see Nölke 2015 as a survey). Northern countries with coordinated wage bargaining systems were able to maintain competitiveness; southern countries with less coordinated wage bargaining systems experienced a loss of competitiveness. The decline in competitiveness in the periphery is explained as the result of lack of wage restraint in the non-tradeable sectors among which the public-sector wages are singled out as the main culprit. Current account imbalances are thereby analysed as result of cost differences, and there is little concern for financialization. Ultimately this story regards a fixed exchange rate system and excessive wage growth in the service sectors in the southern European countries as the root of the crisis.

Recently, some VoC authors have made a step towards a greater consideration of aggregate demand and finance. Baccaro and Pontusson (2016) embrace the post-Keynesian idea of different demand-driven growth models. They provide an analysis of growth models of four European countries prior to the crisis, but with a stronger focus on export performance than on financialization. Johnston and Regan (2017) offer an explanation for cross-country variation in house price inflation centred on the role of labour market institutions. They show econometrically that in countries where the export sector sets the pace for wage growth, moderate income growth tames the demand for mortgage credit and thereby house prices. But they neither cover boom bust phases nor do they allow for speculative dynamics in house prices.

Overall, there are differences in the analytical framework and some agreements as well as some disagreements. $\mathrm{VoC}$ has been criticised for overemphasising the functionality and the stability of the regimes (Heyes et al. 2012; Peck and Theodore 2007; Streeck 2012). While VoC requires internal coherence and external competitiveness for a viable model, we regard the debt-driven and export-driven models as unstable in the longer term. VoC regards labour relations as the 
key institutional structure that shapes models of capitalism, whereas we highlight that financialization has played a key role in the neoliberal era. Overall, $\mathrm{VoC}$ has a strong focus on supply-side factors, albeit in a much richer form than mainstream economics, but has no systematic analysis of demand formation. While recently there have been efforts to move away from the supply-side focus (Baccarro and Pontusson 2016), it remains to be seen whether demand regimes can be integrated into the $\mathrm{VoC}$ framework without losing its internal coherence.

\section{Conclusion}

Financialization has been analysed from many angles. This article took a macroeconomic perspective by linking financialization to the post-Keynesian notion of demand regimes. First, we argued that the degree to which households are financialized partly determines if countries adopt a debt-driven demand regime or an export-driven demand regime. Examining the decade prior to the crisis (2000-2008), we found that while northern European economies deepened their export-driven model with only moderate financialization, southern and Anglo-Saxon countries developed a debt-driven model with a key role for the financialization of households in the form of household debt and property price inflation. Eastern Europe only experienced a moderate level of financialization, and its economic development was strongly shaped by catching-up through FDI-based industrialisation.

Second, we argued that the export-driven and the debt-driven demand regime are intimately linked to each other, but ultimately unstable. The export-driven model relies on debt-financed imports abroad. The debt-driven economies receive capital inflows from the surplus economies financing their boom in consumption, residential investment, and ultimately imports. This configuration of demand regimes in advanced economies has fostered divergent economic performance and gives rise to macroeconomic instability. The debt-driven model is intrinsically unstable as it is prone to a domestic debt crisis once the bubble in property prices bursts. The export-driven model hinges on the macroeconomic performance of its trading partners, which it partly undermines through destabilising capital flows.

Third, we showed that, the pre-crisis configuration has not fundamentally changed. While the southern and eastern European countries have managed to reduce their current account deficits somewhat, the Anglo-Saxon countries have maintained their deficits and the northern European countries have even increased their surpluses. There has been some deleveraging in the Anglo- 
Saxon and southern European countries, which was contractionary in southern Europe. This is characteristic of the downturn phase of the financial cycle and illustrates that debt-drivenness can go both ways. Deleveraging thus does not by itself imply a revision of the debt-driven model.

Our approach has some overlap with recent IPE contributions that have highlighted financialization, but we place a stronger focus on demand formation. Moreover, we share the comparative approach of $\mathrm{VoC}$ by employing a topology of regimes but highlight the importance of financialization and identify instabilities rather than functional complementarities. The contribution of PKE to the analysis of financialisation consists of its macroeconomic framework and its theory of demand regimes. Its relative weakness is its lack of a theory of the state and power relations between political actors. We note the following topics for future research: First, different sectors may experience financialisation at different points in time. While we have, looking backward, emphasised the role of house hold debt, future crisis may centre on business debt. Second, the position of countries in the international hierarchy of currencies matters, in financial crisis even more so than during the boom. Third, state policies not only shape institutions that may foster or channel financialisation, but they also play a critical role for economic performance through their expenditures, which may stabilise or even constitute demand regimes. Different social coalitions and political settlements may result in different uses of the proceeds of a debt-driven boom as well as to different government strategies in the event of crisis. Future research on comparative capitalisms will have to balance the institutional and demand formation analysis. 


\section{References}

Amable, B., 2003. The Diversity of Modern Capitalism. Oxford: Oxford University Press.

Baccaro, L. and Pontusson, J., 2016. Rethinking Comparative Political Economy: The Growth Model Perspective. Politics \& Society, 44(2), pp.175-207.

Barba, A. and Pivetti, M., 2009. Rising household debt: Its causes and macroeconomic implications - a long-period analysis. Cambridge Journal of Economics, 33, pp.113137.

Becker, J. and Jäger, J., 2012. Integration in Crisis: A Regulationist Perspective on the Interaction of European Varieties of Capitalism. Competition and Change, 16(3), pp.169-87.

Blyth, M., 2016. Policies to overcome stagnation: the crisis, and the possible futures, of all things euro. European Journal of Economics and Economic Policies: Intervention, 13(2), pp.215-228.

Blyth, M. and Matthijs, M., 2017. Black Swans, Lame Ducks, and the mystery of IPE's missing macroeconomy. Review of International Political Economy, 24(2), pp.203231.

Bhaduri A. and Marglin S., 1990, Unemployment and the real wage: The economic basis for contesting political ideologies. Cambridge Journal of Economics, 14, pp.375-393.

Brown, A., Spencer, D.A., Veronese Passarella, M., 2017. The extent and variegation of financialisation in Europe: A preliminary analysis. Revista de Economía Mundial, 46, pp. 49-69.

Boyer, R., 2000. Is a Finance-led growth regime a viable alternative to Fordism? A preliminary analysis. Economy and Society, 29(1), pp.111-145.

Crouch, C., 2009. Privatised Keynesianism: An Unacknowledged Policy Regime. The British Journal of Politics and International Relations, 11, pp.382-399.

Dünhaupt, P., 2016. Determinants of labour's income share in the era of financialisation. Cambridge Journal of Economics, 41(1), pp.283-306.

Dutt, A., 2006. Maturity, Stagnation and Consumer Debt: A Steindlian Approach. Metroeconomica, 57(3), pp.339-64.

Frank, R.H., Levine, A.S. and Dijk, O., 2014. Expenditure Cascades, Review of Behavioral Economics, 1, pp.55-73.

Guschanski, A. and Stockhammer, E., 2017. Are current accounts driven by competitiveness or asset prices? A synthetic model and an empirical test. PKSG Working Paper 1716

Guttmann, R., 2016. Finance-led Capitalism: Shadow Banking, Re-Regulation, and the Future 
of Global Markets. New York: Palgrave Macmillan

Hall P., 2014. Varieties of capitalism and the Euro crisis. West European Politics, 37(6), pp.1223-1243.

Hall P. and Soskice D., 2001. An introduction to varieties of capitalism. In: Hall P.A. and

Soskice D. (eds) Varieties of Capitalism. Oxford: Oxford University Press, pp.1-68.

Hale, G. and Obstfeld, M., 2016. The euro and the geography of international debt flows.

Journal of the European Economic Association, 14(1), pp.115-144.

Hassel A., 2014. Adjustments in the Eurozone: Varieties of capitalism and the crisis in southern Europe. LEQS Paper No. 76/2014. Available at: http://www.lse.ac.uk/europeanInstitute/LEQS\%20Discussion\%20Paper\%20Series/LE QSPaper76.pdf [Accessed 13 Jan. 2019].

Hein E., 2012. The Macroeconomics of Finance-Dominated Capitalism - And Its Crisis.

Cheltenham: Edward Elgar.

Hein E., 2013. The crisis of finance-dominated capitalism in the Euro area, deficiencies in the economic policy architecture, and deflationary stagnation policies. Journal of Post Keynesian Economics, 36(2), pp.325-354.

Hein, E., 2014. Distribution and Growth after Keynes. A Post-Keynesian Guide, Cheltenham: Edward Elgar.

Hein, E., 2017. Post-Keynesian macroeconomics since the mid-1990s - main developments, European Journal of Economics and Economic Policies: Intervention, 2017, 14 (2), pp.131-172.

Heyes J., Lewis P. and Clark I., 2012. Varieties of capitalism, neoliberalism and the economic crisis of2008-?, Industrial Relations Journal,43(3), pp. 222-241.

Johnston A., Hancké, B. and Pant S., 2014. Comparative Institutional Advantage in the European Sovereign Debt Crisis. Comparative Political Studies, 47(13), pp.17711800.

Johnston, A. and Regan, A., 2017. Global Finance, Labor Politics, and the Political Economy of Housing Prices, Politics \& Society, 45(3), pp.327-358.

Karwowski, E., Shabani, M. and Stockhammer, E., 2017. Financialization: Dimensions and Determinants. A Cross-Country Study. Kingston University Economics Discussion Papers 2017-1. Available at: https://eprints.kingston.ac.uk/37295/1/2017_001.pdf [Accessed 13 Jan. 2019]

Kim, Y.K., Setterfield, M. and Mei, Y., 2015. Aggregate consumption and debt accumulation: 
an empirical examination of US household behaviour. Cambridge Journal of Economics, 39(1), pp.93-112.

Kohler, K., Guschanski, A., and Stockhammer, E., 2018. The impact of financialisation on the wage share. A theoretical clarification and empirical test, Kingston University Economics Discussion Papers 2018-1.

https://kunet.kingston.ac.uk/ ku33681/RePEc/kin/papers/2018_001.pdf [Accessed 13 Jan. 2019]

Krippner, G., 2005. The financialization of the American economy. Socio-Economic Review, 3, pp.173-208.

Lane, P.R. and McQuade, P., 2014. Domestic Credit Growth and International Capital Flows. Scandinavian Journal of Economics, 116(1), pp. 218-252.

Lavoie, M., 2009. Introduction to Post-Keynesian Economics, Basingstoke: Palgrave Macmillan

Lavoie, M., 2014 Post-Keynesian Economics. New Foundations, North Hampton, MA: Edward Elgar

Nölke A., 2016. Economic causes of the Eurozone crisis. The analytical contributions of comparative capitalism. Socio-Economic Review, 14(1), pp.141-161.

Nölke, A., and Vliegenthart, A., 2009. Enlarging the Varieties of Capitalism: The Emergence of

Dependent Market Economies in East Central Europe. World Politics, 61(4), pp.670702.

Overbeek, H., 2012. Sovereign Debt Crisis in Euroland: Root Causes and Implications for European Integration. The International Spectator, 47(1), pp.30-48.

Orhangazi, Ö., 2008. Financialisation and capital accumulation in the non-financial corporate sector: A theoretical and empirical investigation on the US economy: 1973-2003. Cambridge Journal of Economics, 32, pp.863-886.

Peck J. and Theodore N., 2007. Variegated capitalism. Progress in Human Geography, 31, pp. $731-772$.

Prasad, M., 2012. The Land of Too Much. American Abundance and the Paradox of Poverty. Cambridge: Harvard University Press.

Skott, P. and Ryoo, S., 2008. Macroeconomic implications of financialisation. Cambridge Journal of Economics, 32, pp.827-862.

Ryner, M., 2015. Europe's Ordoliberal Iron Cage: Critical Political Economy, the Euro Area Crisis and its Management. Journal of European Public Policy, 22(2), pp.275-94. 
Stockhammer E., 2004. Financialization and the slowdown of accumulation, Cambridge Journal of Economics, 28, pp.719-41.

Stockhammer E., 2011. Peripheral Europe's debt and German wages. International Journal for Public Policy, 7(1-3), pp.83-96.

Stockhammer E., 2015. Rising inequality as a cause of the present crisis, Cambridge Journal of Economics, 39, pp.935-958.

Stockhammer E., 2016. Neoliberal growth models, monetary union and the Euro crisis. A postKeynesian perspective. New Political Economy, 21(4), pp.365-379.

Stockhammer, E., 2017. Determinants of the wage share. A panel analysis of advanced and developing economies, British Journal of Industrial Relations, 55, pp.3-33.

Stockhammer, E. and Köhler, K., 2014. Linking a post-Keynesian approach to critical political economy: Debt-driven growth, export-driven growth and the crisis in Europe. In Jäger, J. and Springler, E. (eds) Asymmetric Crisis in Europe and Possible Futures: Critical Political Economy and Post-Keynesian Perspectives, New York, Routledge, pp.34-49.

Stockhammer, E., Durand, C., and List, L., 2016. European growth models and working class restructuring: An International post-Keynesian Political Economy perspective. Environment and Planning A, 48(9), pp.1804-1828.

Stockhammer E. and Wildauer R., 2016. Debt-driven growth? Wealth, distribution and demand in OECD countries, Cambridge Journal of Economics, 40(6), pp.1609-1634.

Stockhammer E and Wildauer R., 2017. Expenditure Cascades, Low Interest Rates or Property Booms? Determinants of Household Debt in OECD Countries, PKSG Working Paper 1710

Storm, S. and Naastepad, C.W.M., 2015. NAIRU economics and the Eurozone crisis. International Review of Applied Economics, 29(6), pp.843-877.

Streeck W., 2012. E pluribus unum? Varieties and commonalities of capitalism. MPIfG Discussion Paper 10/12.

Tori, D., and Onaran, Ö., 2018. Financialization, financial development and investment. Evidence from European non-financial corporations, Socio-Economic Review, advance access:https://academic.oup.com/ser/advance-articleabstract/doi/10.1093/ser/mwy044/5258079?redirectedFrom=fulltext.

Watson, M., 2010. House Price Keynesianism and the Contradictions of the Modern Investor Subject. Housing Studies, 25(3), pp.413-426.

van Treeck, T., 2009, A synthetic, stock-flow consistent macroeconomic model of “financialisation", Cambridge Journal of Economics, 33, pp.467-493 
Zabai, A., 2017. Household debt: recent developments and challenges. BIS Quarterly Review, March 2017, pp.39-54. 